\title{
DAMPAK REVOLUSI INDONESIA PADA NASKAH DRAMA TITIK- TITIK HITAM DAN AWAL \& MIRA
}

\author{
Fanisa Qorina Zahro ${ }^{1}$, Novi Diah Haryanti ${ }^{2)}$ \\ ${ }^{1}$ Universitas Islam Negeri Syarif Hidayatullah Jakarta \\ email: fanisa.zahro17@mhs.uinjkt.ac.id \\ ${ }^{2}$ Universitas Islam Negeri Syarif Hidayatullah Jakarta \\ email: novi.diah@uinjkt.ac.id
}

\begin{abstract}
Abstrak
Penelitian ini bertujuan memperoleh pengetahuan tentang dampak revolusi Indonesia yang dikisahkan melalui sastra dan seni, salah satunya adalah drama. Kemerdekaan Indonesia ternyata tidak menjadikan negara ini seutuhnya merdeka. Banyak pengorbanan yang kembali harus diperjuangkan pascakemerdekaan, sebab kerajaan Belanda masih ingin menjajah dan menguasai Indonesia yang saat itu baru saja memproklamasikan kemerdekaan. Peralihan sistem ketatanegaraan menjadi negara yang merdeka dan perebutan kekuasaan antara Indonesia dengan Belanda menimbulkan sejumlah konflik dan peristiwa. Peperangan, perundingan, pemberontakan, dan pembunuhan terjadi saat itu. Sejarah mencatat masa kelam itu, namun di tangan para sastrawan peristiwa tersebut dikemas dengan tampilan yang berbeda. Salah satunya adalah Nasjah Djamin dan Utuy Tatang Sontani. Keduanya mengangkat kisah-kisah manusia yang mengalami kesakitan dan penderitaan akibat revolusi yang kemudian disuguhkan untuk mengenang bagaimana arti kemerdekaan yang sesungguhnya melalui karya-karyanya.
\end{abstract}

Kata Kunci: revolusi, drama, pascarevolusi, titik-titik hitam, awal dan mira.

\section{Abstract}

This study aims to gain knowledge about the impact of the Indonesian revolution which is narrated through literature and art, one of which is drama. Indonesian independence apparently did not make this country fully independent. Many sacrifices returned had to be fought for after independence, because the Dutch kingdom still wanted to colonize and rule Indonesia, which at that time had just proclaimed independence. The transition of the constitutional system to an independent state and the struggle for power between Indonesia and the Netherlands caused a number of conflicts and events. War, negotiations, rebellion and assassination took place at that time. History records the dark period, but in the hands of writers the event is packaged with a different look. One of them is Nasjah Djamin and Utuy Tatang Sontani. Both of them raised stories of people who experienced pain and suffering due to the revolution which were then presented to commemorate the true meaning of independence through his creation.

Keywords: revolution, drama, postrevolution, titik-titik hitam, awal and mira.

\section{PENDAHULUAN}

Nasjah Djamin dan Utuy Tatang Sontani adalah dua penulis yang karya- karyanya banyak menerbitkan tentang bagaimana kondisi sosial, khususnya kondisi sosial Indonesia masa revolusi sampai pascarevolusi. Keduanya berhasil membuat karya yang memuat nilai-nilai pascarevolusi, Titik-Titik Hitam dengan Awal dan Mira salah satunya. Mereka berhasil menyuguhkan sebuah lakon yang berangkat dari rasa penderitaan, penindasan, pengkhianatan, kesakitan, dan kepercayaan, serta menghadirkan sebuah mitos-mitos yang terlahir dari kemerdekaan sebuah bangsa.
Situasi Indonesia yang sedang kacau akibat perang revolusi menghantarkan beberapa sastrawan untuk menuangkan realitas tersebut ke dalam tulisan. Titik- Titik Hitam karya Nasjah Djamin dan Awal dan Mira karya Utuy Tatang Sontani salah satunya. Dua naskah drama tersebut mengisahkan bagaimana keadaan negara Indonesia dan kehidupan masyarakat setelah terjadinya perang revolusi. Penulis-penulis tersebut menunjukkan bagaimana bentuk rasa penderitaan, dampak peperangan dan nilai-nilai kemanusiaan, pengkhianatan, kemunafikan, kepahlawanan, dan pengorbanan yang terjadi selama masa revolusi. 
Menurut T.B. Simatupang (1987: 1), hakikat dari revolusi kemerdekaan di Indonesia adalah membebaskan masyarakat Indonesia dari kaum penjajah, yang sudah berabad-abad menduduki Indonesia. Revolusi ini dapat dilihat sebagai loncatan melalui dua tahap, pertama, loncatan dari penjajahan ke alam merdeka, dan kedua, loncatan dari masyarakat yang diwariskan oleh zaman penjajahan dan perang kemerdekaan yang bertahun-tahun ke suatu masyarakat Indonesia yang modern, adil, makmur dan mencerminkan kepribadian kita dan yang mempunyai swadaya untuk perkembangan yang terus-menerus. Nyoman Dekker (1989: 14) berpendapat bahwa kondisi politik, sosial ekonomis, kebudayaan, menyebabkan pengertian revolusi itu erat hubungannya dengan kemerdekaan. Tidak ada kemerdekaan tanpa revolusi, dan tidak ada revolusi tanpa kemerdekaan.

Bukan hanya perubahan mengenai sistem pemerintah dan tatanannya yang terjadi di Indonesia, tetapi juga perubahan perspektif masyarakat terhadap tentara dan perempuan. Tentara yang pada awalnya tidak dihormati pada masa sebelum revolusi menjadi sangat dipuja-puja pada masa revolusi. Mereka dianggap sebagai pelindung bagi rakyat dan juga diakui oleh pemerintah. Sama halnya dengan perempuan. Ritma Fakhrunnisa (2017: 2) berpendapat bahwa perempuan, yang awalnya tidak terlalu diakui keberadaannya, mulai menonjolkan dirinya dengan cara yang berbeda. Kehidupan mereka tidak selalu perihal dapur dan rumah untuk mengurus anak dan suami. Perubahan perspektif itu pun akhirnya menimbulkan pertentangan dalam masyarakat. Kemunculan masalah sosial seperti diorganisasi keluarga dan pelanggaran terhadap norma masyarakat pun tidak dapat dihindarkan kala itu.

Keadaan tersebut tergambar dalam naskah drama Titik-Titik Hitam. Penggambaran tersebut dilukiskan dengan tokoh perempuan, yaitu Hartati dan Rahayu. Hartati adalah tokoh perempuan yang memiliki seorang suami, berasal dari keluarga yang kaya, berpendidikan, aktif berorganisasi sebelum menikah, dan terpandang dalam masyarakat. Penggambaran tokoh Hartati relevan dengan realitas perempuan pada masa itu. Mereka tidak serta-merta menikah dan mengurus keluarga saja, mereka sudah dididik dengan sistem dan pengaruh dari kebudayaan Barat bahwa perempuan tidak hanya mengurus soal rumah saja. Mereka dituntut memiliki kecerdasan, pengetahuan, keterampilan, dan aktif dalam kegiatan-kegiatan di luar rumah.

Tokoh Rahayu juga demikian, ia adalah adik dari Hartati. Rahayu sendiri adalah sosok perempuan yang berpendidikan dan berasal dari keluarga kaya. Ia adalah tokoh yang mendapat pengaruh dari kebudayaan Barat, yaitu sebagai tokoh perempuan yang berani, mandiri, tegas, dan tidak mempermasalahkan hal keperawanan. Rahayu memberikan keperawanannya kepada seorang pilot dan menggugurkan kandungannya. Tokoh Ibu sangat mempermasalahkan perbuatan Rahayu yang dinilai melanggar norma dan adat Timur. Rahayu tetap bersikeras bahwa keperawanan bukan hal yang seharusnya dipermasalahkan, ia berhak bebas dalam menentukan hidupnya. Selain itu, sikap kemandirian dan tegas diperlihatkan Rahayu dengan mengambil keputusan untuk pergi dari rumah. Pola pikir dan keberanian ini tentu didapatkan Rahayu dari pengaruh Barat melalui pendidikan dan organisasi.

Perang revolusi yang terjadi dalam mempertahankan NKRI dari Belanda tidak hanya dilakukan oleh pemerintah dan tentara, tetapi warga sipil ikut andil dalam perjuangan ini. Tidak sedikit korban berjatuhan akibat perang dan mereka harus gugur dalam medan pertempuran. Korban-korban yang selamat juga harus menanggung beban yang begitu besar, tidak sedikit dari mereka yang mengalami luka sampai cacat akibat terkena tembakan senjata, misil, dan bom semasa revolusi. Gambaran ulang keadaan masyarakat Indonesia ketika revolusi dihadirkan melalui tokoh-tokoh yang mengalami kesakitan dan 
penderitaan. Tokoh-tokoh yang hadir dalam menyuguhkan dampak akibat revolusi adalah tokoh Adang dalam Titik-Titik Hitam dan Mira dalam Awal dan Mira. Tokoh Adang disajikan sebagai tokoh suami yang memiliki istri, senang memanjakan istri dengan harta, dan sering dinas keluar kota. Adang harus kehilangan tenaga kejantanan atau tenaga kelaki-lakian, Adang mengalami kecacatan dari pangkal perut sampai lutut dan hanya ditambal dengan daging tambahan. Akibatnya, Adang tidak bisa memberikan kebutuhan yang lebih bagi Hartati.

Hal serupa juga dialami oleh tokoh Mira. Mira seorang gadis penjual kopi harus terkurung dari dunia luar dan terjebak dalam ketidak berdayaannya. Mira gadis yang harus mengalami kecacatan akibat perang dan juga kemiskinan akibat dari revolusi. Teriakan kata merdeka yang menggema sampai ke penjuru negeri nyatanya hanya mitos dalam naskah Awal dan Mira. Mira dan ibunya ternyata masih harus berjuang untuk memerdekakan diri di tengah keadaan ekonomi yang tidak stabil walau keadaan negara Indonesia sudah merdeka.

Selain menjadi gambaran suatu peristiwa, cerita-cerita tersebut juga menimbulkan pandangan baru bagi pembaca mengenai dampak dari revolusi kemerdekaan di Indonesia, yang dalam sejarah selalu bersifat tunggal dan satu arah. Lebih dari pada mencerminkan kondisi sosial masyarakat pada zamannya. Nasjah Djamin dan Utuy Tatang Sontani seolah berbicara mengenai sisi lain dari sejarah, dampaknya terhadap masyarakat, dan bagaimana kelamnya kehidupankehidupan mereka yang harus berjuang dan menjadi korban revolusi menjadikan masalah utama yang dibahas dalam penelitian ini.

\section{METODE PENELITIAN}

Pendekatan yang akan digunakan dalam penelitian ini adalah pendekatan objektif dan sosiologi. Menurut Hasanuddin W.S. (1996: 110) pendekatan objektif merupakan pendekatan yang sangat mengutamakan penyelidikan karya sastra berdasarkan kenyataan teks sastra itu sendiri. Hal-hal yang diluar sastra walaupun masih ada hubungannya dengan sastra dianggap tidak perlu dijadikan pertimbangan dalam menganalisis karya sastra.

Faruk (2016: 1) dalam bukunya menyatakan bahwa sosiologi menurut Swingewood adalah studi yang ilmiah dan objektif mengenai manusia dalam masyarakat, studi mengenai lembaga- lembaga dan prosesproses sosial. Sosiologi sastra merupakan pendekatan yang bertolak dari orientasi kepada semesta, namun bisa juga bertolak dari orientasi kepada pengarang dan pembaca. Menurut pendekatan sosiologi sastra, karya sastra dilihat hubungannya dengan kenyataan, sejauh mana karya sastra itu mencerminkan kenyataan. Kenyataan di sini mengandung arti yang cukup luas, yakni segala sesuatu yang berada di luar karya sastra dan yang diacu oleh karya sastra.

Sastra menyajikan gambaran kehidupan dan kehidupan itu sendiri sebagian besar terdiri dari kenyataan sosial. Kehidupan mencakup bagaimana hubungan-hubungan antarmasyarakat dengan orang-orang, hubungan- hubungan antarmanusia, dan hubungan-hubungan antarperistiwa yang terjadi di dalam batin seseorang. Kita sebagai pembaca perlu memandang sebuah karya sastra sebagai penggambaran dunia dan kehidupan manusia, kriteria utama yang dikenakan pada karya sastra tersebut adalah sebuah kebenaran penggambaran atau yang hendak digambarkan. Karya sastra dapat juga mencerminkan dan menyatakan segi-segi yang kadang- kadang kurang jelas dalam masyarakat.

Berdasarkan fenomena-fenomena yang terjadi dalam masyarakat tersebut, penulis menggunakan pendekatan objektif sosiologi sastra serta berfokus dengan dampak revolusi Indonesia pada naskah drama Titik-Titik Hitam dan naskah drama Awal dan Mira. Metode yang digunakan adalah metode kualitatif dengan menggunakan kajian sastra bandingan. Menurut Nyoman Kutha Ratna (2013: 46-48), metode kualitatif adalah metode penafsiran 
yang mendeskripsikan suatu data alamiah dengan memperhatikan nilai-nilai yang dikandungnya.

\section{HASIL DAN PEMBAHASAN}

Penggambaran-penggambaran bagaimana sebuah realitas tentang kesedihan dan kehancuran memberikan sisi menarik untuk dapat dituang ke dalam sebuah karya. Kisahkisah kepahlawanan dan perang yang disuguhkan dalam kehidupan masyarakat banyak yang belum mengungkapkan bagaimana sebuah perang itu berdampak lebih dari sebuah membinasakan sekelompok manusia. Dengan mengambil latar waktu antara tahun 1950-1960an, Nasjah Djamin dan Utuy Tatang Sontani berhasil merangkai sebuah kesedihan, pengkhianatan, rasa sakit, kehilangan, penderitaan, dan kekecewaan menjadi sebuah lakon. Kedua karya lakon ini mengambil dua sudut pandang yang pengisahan yang berbeda. Perbedaan sudut pandang ini yang kemudian menghadirkan sebuah alur dan konflik-konflik kompleks yang dilalui oleh tokoh-tokohnya.

Titik-Titik Hitam dan Awal dan Mira hadir untuk memperlihatkan bagaimana sebuah dampak yang ditimbulkan akibat adanya peperangan di masa revolusi. Kisah ini disimbolkan melalui tokoh- tokohnya yang menjadi sebuah gambaran umum bagaimana masyarakat Indonesia yang pada saat itu merasakan langsung dampak dari revolusi ini. Dampak tersebut tidak hanya dirasakan oleh tokoh-tokoh yang berperan menjadi seorang tentara atau pejuang, tetapi juga warga sipil.

Lakon Titik-Titik Hitam mengambil latar rumah di suatu kota, latar tersebut yang kemudian menjadikan tokoh- tokohnya adalah orang yang berkecukupan, berpendidikan, mapan, dan bisa mengembangkan kemauan dan bakatnya. Dampak revolusi di Indonesia dalam naskah drama Titik-Titik Hitam ini dikisahkan melalui sudut pandang seorang mantan pejuang. Tokoh yang dihadirkan dalam penggambaran seorang mantan pejuang yang ikut berperang dalam revolusi adalah Adang.
Adang dikisahkan sebagai seorang lelaki yang sudah memiliki istri bernama Hartati. Hartati dan keluarganya diboyong oleh Adang untuk tinggal bersama di rumahnya. Adang adalah seorang suami yang pekerja keras, baik, suka memanjakan istrinya Hartati dengan memberikan kemewahan, sukabepergian untuk dinas di luar kota, dan berasal dari golongan yang mencukupi.

Hartati: "Suamiku tak usah dipersoalkan. Aku bahagia. Ia suami yang baik, terlalu baik. Lihatlah apa yang kurang padaku? Aku ditimbunnya dengan harta, aku kilau-kemilau, segala kesenangan benda ditumpukkannya di kakiku. Semua kemauanku diperturutkannya. Ia suami yang baik".

Awal drama ini dibuka dengan menyuguhkan sebuah konflik antara Ibu Hartati dan Adang. Ibu mengatakan dan menuduh Adang bahwa ia adalah laki- laki yang tidak baik dan membuat Hartati kecewa. Adang disalahkan atas semua yang terjadi dengan Tati. Sebagai seorang suami, Adang sudah memberikan yang terbaik bagi Tati, namun semua itu ternyata dirasa belum cukup oleh Ibu. Sedang Adang menyangkal tuduhan Ibu dan menyatakan bahwa sebenarnya Ibulah yang membuat semua kekacauan ini. Semua disebabkan karena Ibu yang tidak suka dengan perkawinan antara Adang dan Tati.
Adang: "(Menepis udara dengan tangannya, menunjukkan kesalnya) Tak usahlah Ibu cakap-cakap tentang derita. Yang ibu kehendaki kehancuran hidupku. Kehancuran Tati. Tidak? Itulah yang ingin Ibu lihat. Ia lihatlah, lihat puas-puas hidup kami yang sudah jadi puing ini. (Ibu sebagai orang yang kena pukul oleh kata-kata Adang yang tidak memberinya kesempatan membuka mulut.) Begitu besar cinta Ibu pada anak? Dari dulu Ibulah yang kurang suka pada perkawinan kami. Tapi cinta Tati dan aku lebih besar dan lebih kuat. Itu yang mau Ibu hancurkan. Bila Ibu 
memang benci pada diriku, kenapa tidak aku sendiri yang diracun? Sekali inilah baru aku melihat seorang Ibu yang sampai hati menghancurkan hidup anaknya sendiri. Dan masih bisa berkata ia cinta pada anaknya. Masih bisa berkata, deritanya sudah sampai ke puncaknya! (Lalu geramnya bertambah nyala melihat Ibu yang dia menunduk sebagai tak mendengarkan itu) puas Ibu sekarang sudah! (Suaranya begitu lengking)"

Konflik permasalah ini dihadirkan melalui perselingkuhan yang dilakukan oleh Hartati dengan Trisno, adik Adang. Hartati digambarkan sebagai seorang perempuan yang berpendidikan, mandiri, seorang aktivis, dan tidak berani mengambil sebuah resiko.

Trisno: "(Setelah berdiam diri) Aku heran kenapa kau tidak ikut bergerak di lapangan masyarakat. Kau seorang wanita muda, terpelajar, modern, dan cukup. Lapanganmu bekerja di luar rumah banyak."

Sedangkan penokohan Trisno dilukiskan sebagai seorang laki-laki berusia 26 tahun, berjiwa bebas, suka melukis, senima, dan berani.

Ibu: "Itu potret Tati, Trisno yang melukisnya. Persis ya, Pak Dokter?"

Dr. Gun: "Ya, seperti Tati sendiri"

Dr. Gun: "Oho, janganlah membantah.

Selamat Tris, moga-moga kalian berdua dilimpahi bahagia. (Menjabat tangan Trisno yang ragu-ragu) Ah, mukamu ini suram lagi! Orang muda harus gembira.

Baik itu, kalian lekas- lekas kawin sewaktu masih muda. Berapa umurmu sekarang?

Trisno: "Dua puluh enam".

Konflik dalam pengisahan ini menarik pembaca untuk kembali pada masa lalu tokoh Hartati dan Trisno, kita dibawa kembali pada masa awal-awal mereka berselingkuh. Saling merasakan kasih sayang dan bersuka-sukaan. Konflik percintaan ini juga tidak hanya terjadi oleh Tati dan Trisno, tetapi Rahayu, adik Tati juga terlibat di dalamnya. Rahayu yang memiliki perasaan kepada Trisno merasa bahwa Tati merebutnya dari Rahayu dan mengkhianatinya. Sama seperti Hartati yang berpendidikan dan modern, tokoh Rahayu juga adalah perempuan yang modern, berpendidikan, dan berani.

Perselingkuhan ini kemudian mencapai klimaks dengan menggambarkan keadaan Tati yang hamil dan mengandung anak dari Trisno. Hal ini terjadi karena Hartati yang tidak terpenuhi kebutuhannya oleh Adang dan mencari pelampiasan kebutuhannya tersebut dengan Trisno. Adang selalu sibuk dinas bekerja ke luar kota sehingga Tati merasa kesepian di rumah. Tetapi ternyata pernyataan Hartati yang merasa kesepian mengandung maksud lain, ia tidak hanya sekadar merasakan sebuah kesepian karena ditinggal bekerja. Di balik perasaan itu, Hartati merasakan bahwa ada kebutuhan dan kesepian yang lebih dari itu, yaitu adalah kebutuhan seksualnya yang tidak terpenuhi dan tidak didapat dari Adang suaminya. Adang adalah salah satu dari sekian banyak korban akibat perang revolusi di Indonesia. Adang sempat ikut berperang dalam peristiwa revolusi di Indonesia. Ia berjuang untuk kemerdekaan tanah air dan menghadapi maut untuk revolusi. Tetapi revolusi memberinya sebuah siksaan, ia terkena mortir. Ia harus mengalami kecacatan dari pangkal perut sampai lutut. Akibatnya bagian dari tubuh Adang merupakan daging tambalan. Adang merasa mengapa ia ditakdirkan Tuhan untuk bisa selamat dari mortir tersebut dan menerima kenyataan bahwa istrinya berselingkuh dengan adiknya sendiri.

Adang : "(Tersedu) Kutuk apa yang menimpa aku. Kutuk apa? Aku kehilangan segalanya, kemanusiaanku. Aku berjuang untuk kemerdekaan tanah air, aku menghadapi maut untuk revolusi. Tapi revolusi memberi aku siksaan ini. Lihatlah, aku sekarang. Seorang cacat. Dari pangkal perut sampai lututku hanya merupakan daging 
tambalan. O, kenapa aku harus dihidupkan Tuhan, kenapa aku tidak dimatikan saja waktu mortir itu memecah. Dan aku harus menerima takdir ini!"

Alur dalam drama Titik-Titik Hitam ditutup dengan akhir penyelesaian, Adang sangat kecewa dengan Trisno dan Hartati atas perbuatan yang mereka lakukan. Ia menyuruh Trisno untuk membunuhnya dengan sebuah pisau yang pernah digunakan untuk bunuh diri dan pisau yang digunakan untuk membunuh serdadu Belanda di zaman revolusi. Adang yang tidak tahan dengan kecacatan dan penderitaan yang diakibatkan oleh revolusi berkali-kali mencoba bunuh diri dengan pisau tersebut.

Titik-Titik Hitam memperlihatkan bagaimana setiap tokoh-tokohnya memiliki penggambaran masa lalu dan dosa-dosanya tersendiri. Berangkat dengan latar revolusi, pembaca dibawa untuk menyimak bagaimana suasana dan dampak yang ditimbulkan akibat revolusi. Banyak kepedihan, luka, kekecewaan, rasa sakit, kehilangan, dan penyesalan. Itu semua merupakan dampakdampak yang dapat kita tinjau dari segi akibat yang buruk. Tetapi jika kita lihat dari sisi tokoh Rahayu, Hartati, Trisno, Adang, dan dr. Gun adalah tokoh- tokoh yang diceritakan sebagai sosok terpelajar, modern, berpikiran luas, dan memiliki pekerjaan yang mapan. Ini merupakan dampak dari adanya modernisasi yang dibawa oleh Belanda ketika menjajah Indonesia. Modernisasi tersebut yang kemudian membawa alur pengisahan menjadi sebuah konflik yang kompleks.

Jika sebelumnya dampak revolusi Indonesia diceritakan dengan sudut pandang seorang mantan pejuang, dalam naskah drama Awal dan Mira ditampilkan dampak revolusi Indonesia melalui sudut pandang warga sipil. Sudut pandang ini menampilkan sosok tokoh bernama Mira. Mira adalah seorang perempuan cantik yang menjual kopi dan tinggal bersama Ibunya yang sudah lanjut usia. Mereka berdua adalah tokoh yang berasal dari golongan bawah. Mira adalah penggambaran korban dari adanya peristiwa revolusi di Indonesia. Mira harus mengalami penderitaan dengan kehilangan kedua kakinya sehingga ia mengalami kecacatan. Sebuah ironi yang menyedihkan. Penderitaannya tidak hanya berhenti dari kecacatan yang menimpanya.

Mengambil sebuah latar tahun 1951 dan tempat sebuah perkampungan penduduk yang jauh dari keramaian, membuat tokoh-tokohnya adalah gambaran orang-orang yang menengah sampai menengah ke bawah. Mereka adalah gambaran orang-orang yang belum bisa merasakan kemerdekaan, harus berjuang untuk memerdekakan diri sendiri, dan kemerdekaan itu sendiri merupakan mitos bagi mereka semua. Mereka harus memerdekakan diri mereka sendiri dengan cara yang sulit. Hidup dengan keterbatasan fisik dan keterbatasan keadaan. Kemerdekaan tidak serta-merta menghadirkan 'kemerdekaan' yang nyata bagi tokoh Mira dan Ibunya.

Hal ini diperlihatkan oleh Mira dan Ibunya yang harus mendirikan sebuah kedai kopi di serambi muka rumah dan terbuat dari bambu yang baru didirikan tetapi berukuran kecil. Sebuah euforia kemerdekaan yang tidak pernah dirasakan oleh Mira dan Ibunya. Peristiwa ini terjadi pada suatu malam dalam tahun 1951 di depan kedai kopi kepunyaan seorang perempuan cantik bernama Mira. Yang dimaksud kedai kopi kepunyaan Mira itu sebenarnya serambi muka dari rumah Mira yang dibangun jadi kedai kopi. Dan rumah Mira itu rumah bambu, kecil tapi masih baru, letaknya menghadap ke jalan, didirikan di atas bekas runtuhan rumah batu yang hancur oleh peperangan, terpencil jauh dari keramaian.

Awal pengisahan drama ini sudah menunjukan bagaimana Mira yang harus bertahan hidup dengan menjual kopi, sesekali ia harus memutar otak dalam mendapatkan keuntungan. Salah satunya adalah memanfaatkan parasnya yang cantik. Rupanya yang cantik mampu menutup kekurangan fisik Mira dari para pelanggan-pelanggannya. Ia suka meminta kembalian pelanggannya 
sebagai upah karena mereka sudah memandang dan menikmati wajah Mira yang cantik.

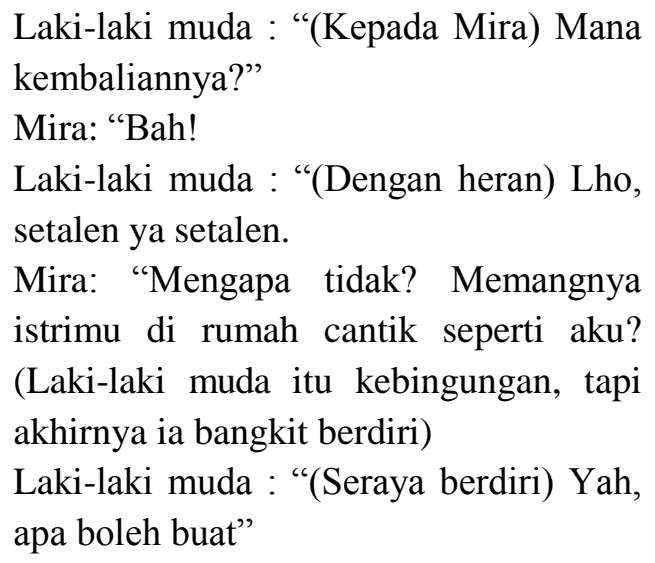

Mira menyukai seorang pemuda bernama Awal. Awal adalah seorang laki-laki kurus berumur antara 27 dan 30 tahun dan berasal dari golongan yang berada.

Mira: “(Kepada Ibunya seraya masuk ke dalam rumah) Katakan saja saya pergi ke toko! (Laki-laki yang bernama Awal itu berumur antara 27 dan 30 tahun. Badannya kurus, rambutnya gondrong tidak dipelihara. Dan ia datang ke depan kedai dengan langkah lesu terhuyunghuyung. Berat bunyi suaranya sewaktu bicara)".

Mira yang cantik dan malang diperebutkan oleh laki-laki yang sering mampir ke kedai kopi miliknya. Mereka semua tidak mengetahui kekurangan dari Mira. Alur mundur ke belakang ditampilkan melalui tokoh-tokoh tambahan, Laki-laki Tua berumur 58 tahun. Ia mengisahkan sedikit kehidupannya sebelum terjadi peperangan. Memiliki rumah yang seperti gedung, namun itu semua sudah hancur akibat adanya peperangan.

Laki-laki Tua: "Kalau rumah yang kudiami sekarang sebesar rumahku sebelum peperangan dulu, tak apa aku membuka mata di rumah pada malam hari, sebab pemandangan tidak sempit. Tapi rumahku sekarang, hm, namanya saja sudah bukan rumah, hanya cukup untuk tidur."
Ibu Mira: "Tapi di zaman sekarang ini sudah umum begitu", kata Ibu Mira seraya menyodorkan gelas teh pahit.

Kehidupan sebelum perang yang begitu mendamaikan dan menyejahterakan setiap individu berubah karena harus menghadapi peperangan, kenyataan berubah menjadi kepedihan dan kepiluan. Segala yang dimiliki harus hilang begitu saja. Perjuangan yang harus dikorbankan demi perang yang entah untuk siapa tetapi berdampak pada semuanya.

Konflik dalam naskah ini menjadi puncaknya ketika hati Mira hanya berlabuh kepada Awal dan begitupun sebaliknya. Awal yang sangat mencintai Mira dan memiliki hasrat untuk bisa berkawan selamanya dengan Mira terjebak antara rasa cinta dan keterbatasan Mira. Tokoh Awal yang memiliki krisis kepercayaan hanya ingin Mira menjadi tempat satu-satunya ia bisa memercayakan segalanya, namun Mira yang sadar diri dan tidak ingin mengecewakan Awal membuat keputusan besar, mengakui kekurangannya kepada Awal. Keputusan Mira tersebut membuat keduanya tidak pernah bisa bersatu. Kejujuran Mira akan keadannya ternyata membuat Awal sangat terkejut dan tidak bisa percaya akan kenyataan yang harus didengarnya.

Mira: "(Seraya menyapu-nyapu air mata di pipi) Ya, Mas, inilah kenyataanku. Kakiku dua-duanya buntung. Buntung karena peperangan. Tapi lantaran inilah, Mas, lantaran ke atas aku cantik dan ke bawah aku cacat, aku bagimu merupakan paduan dari keindahan surga yang kau mimpikan dan kepahitan dunia yang kau rasakan. merupakan wanita utama. Tapi sekarang. (Awal yang berbadan kurus itu mundur lagi. Dan mundur lagi. Tangannya yang gemetar berdarah diacuhkan. Mulutnya menganga)

Awal: "(Hampir tak kedengaran) Mi...(Tiba-tiba memekik) Mi....Miraaaaaaa! (Langsung jatuh tertelungkup) (Mira segera mendapatkan. Badan Awal yang kurus itu 
dirangkulnya)

Kekejaman yang terjadi di Indonesia ketika peristiwa revolusi adalah sebuah bentuk kekerasan ekstrem Belanda di Indonesia. Kekejaman itu terlihat bagaimana mereka datang dan menyerbu Indonesia kembali, keadaan tentara Belanda yang kekurangan pasukan menjadikan mereka harus menyerang siapa saja yang dianggap pribumi dan musuh. Mereka melemparkan mortir- mortir kepada musuh bahkan penduduk sipil. Mereka juga tidak segan untuk menghancurkan permukiman penduduk dengan cara membakarnya. Hal-hal tersebut mereka lakukan dengan kejam tanpa pandang bulu. Mereka menghilangkan rasa kemanusiaan untuk mengabdi kepada negaranya.

Kemudian peristiwa-peristiwa ini yang memberikan dampak besar, khususnya bagi Indonesia sebagai negara yang sedang berserteru dengan Belanda. Perang tidak memandang siapa lawan dan siapa yang harus dilawan. Perang hanya memegang teguh, pengorbanan dilakukan untuk mengabdi kepada negara dengan segala perjuangan meski harus gugur sebagai pahlawan bahkan mereka harus menjadi pahlawan yang tidak dikenang.

Tokoh-tokoh dalam naskah drama TitikTitik Hitam dan Awal dan Mira merupakan korban dari kejamnya revolusi yang terjadi di Indonesia. Mereka bukanlah hanya sebuah korban yang berjatuhan akibat adanya peperangan, mereka adalah sebuah bagian dari kisah revolusi Indonesia yang tidak terungkap. Titik-Titik Hitam dan Awal dan Mira memperlihatkan bahwa dampak dari sebuah revolusi bukan hanya ditinjau dari segi fisik, tetapi psikologis mereka juga ikut terpengaruhi. Bagaimana penderitaan dan takdir yang tidak pernah mereka harapkan harus dijalani dengan kepura-puraan.

\section{KESIMPULAN}

Adapun kesimpulan dari penelitian ini sebagai berikut:

a. Belanda yang menyerang dan ingin menguasai Indonesia kembali melakukan kekejaman terhadap Indonesia. Belanda tidak segan menembakkan mortir dan timah panas, membumihanguskan permukian penduduk, dan menembah warga sipil Indonesia.

b. Penulis berhasil menampilkan sisi- sisi kepedihan, luka, pengkhianatan, kekecewaan, dan penderitaan melalui sebuah lakon.

c. Lakon ini juga merupakan sebuah kritik di mana sebuah arti kemerdekaan yang tidak berlaku bagi masyarakat Indonesia sendiri.

d. Revolusi juga memberikan dampak yang bisa dikatakan sebagai sisi positif. Melalui penggambaran beberapa tokoh, bisa kita lihat bahwa mereka adalah tokoh yang berpendidikan, modern, aktivis, dan memiliki pekerjaan yang mapan.

\section{DAFTAR PUSTAKA}

Dekker, Nyoman. 1989. Sejarah Revolusi Nasional. Jakarta: Balai Pustaka.

Djamin, Nasjah. 1956. Titik-Titik Hitam. Jakarta: Pusat Dokumentasi Sastra

Faruk. 2016. Pengantar Sosiologi Sastra. Yogyakarta: Pustaka Pelajar.

H.B. Jassin. Fakhrunnisa, Ritma, dkk. 2017. "Wajah Indonesia Pascaproklamasi (19451950) Melalui Kumpulan Cerpen Мenuju Kamar Durhaka karya Utuy Tatang Sontani”. Jurnal Arkhais.

Ratna, Nyoman Kutha. 2013. Teori Metode dan Teknik Penelitian Sastra. Yogyakarta: Pustaka Pelajar.

Simatupang, T. B. 1987. Dari Revolusi ke Pembangunan. Jakarta: BPK Gunung Mulia.

Sontani, Utuy Tatang. 1949. Awal dan Mira. Jakarta: Pusat Dokumentasi Sastra H.B. Jassin.

W. S., Hasanuddin. 1996. Drama Karya Dalam Dua Dimensi. Bandung: Penerbit Angkasa. 